\title{
'RESPONSIBILITY' TO PROVIDE: FAMILY Provision Claims IN VICTORIA
}

\section{SAMANTHA RENWICK*}

Family provision legislation was introduced in Victoria in 1906 to allow the court to order provision from the estate of a deceased person whose will did not make adequate provision for the proper maintenance and support of a person for whom the deceased had a moral duty to provide. The first version of the legislation allowed only widows and children to claim; it underwent little reform until 1997 when a major amendment to the Administration and Probate Act 1958 (Vic) removed the statutory list of eligible applicants, and replaced it with the jurisdictional question, 'Did the deceased have a responsibility to provide?' This in theory means that 'anyone' can make a claim, including those without a close family relationship with the deceased. This article examines a selection of judgments handed down under the new provisions, with the aim of showing the range of applicants who are now eligible to apply and examining the particular features of their relationship with the deceased that determined the success of their claims. This is in light of the current Victorian Law Reform Commission Inquiry into Succession Law that questions whether eligibility should be limited to certain types of relationship, and whether costs should continue to be paid out of the estate.

\section{INTRODUCTION}

A family provision claim allows the court to order provision out of the estate of a deceased person for the proper maintenance and support of a person for whom the deceased had a moral responsibility to provide. ${ }^{1}$ What is considered to be 'proper' is relative to all the circumstances of the case. ${ }^{2}$ The practical effect of an order is to alter the provisions of a deceased person's will or the distribution of an estate according to the intestacy provisions of the

\footnotetext{
* LLB (Monash), LLM (AdvLegalPrac) (Monash); Australian Lawyer and Officer of the Supreme Court of Victoria; and current SJD candidate at Monash University. The author would like to thank Associate Professor Matthew Groves of Monash University for helpful suggestions during the editing process. The law is current to 16 August 2013.

${ }^{1}$ Administration and Probate Act 1958 (Vic) s 91(1).

2 Blair v Blair (2004) 10 VR 69, 84 citing Collicoat v McMillan [1999] 3 VR 803, 815; Lee v Hearn (2005) 11 VR 270, 273.
} 
Administration and Probate Act 1958 (Vic). This area of law has always been controversial, but the position in Victoria is especially so following the major reform to the Act in 1997. Under the very first version of the provisions, only widows, unmarried daughters under 21 and sons under 18 could claim. ${ }^{3}$ Immediately prior to the 1997 reform, only widows, widowers, ex-widows in receipt of alimony or maintenance, and children of the deceased were eligible to apply. ${ }^{4}$

The decision in Rowe $v$ Popple ${ }^{5}$ is widely considered to have triggered the 1997 amendment to section 91 of the Act. ${ }^{6}$ The case examined whether it was within the correct construction of the statute to allow step-children to claim as 'children' of the deceased. Nathan J held that the

word 'children' should be given the common meaning it now bears ... [D]istinctions between children 'of the blood' and others are no longer adequate to deal with the technological or biological realities of our time. ... Discrimination against stepchildren who have become children of a marriage is not consistent with the remedial purposes of Pt IV. ${ }^{7}$

This was overturned on appeal, Brooking $\mathrm{J}$ holding that '[r]emedial the legislation no doubt is, but with all the interpretative benevolence in the world one cannot arrive at the contrary result' ${ }^{8}$ The practical effect of this result was that a step-child who was cared for by the deceased, regarded as the deceased's own child and financially dependent on the deceased, was not eligible to claim.

Following the introduction of no fault divorce with the Family Law Act 1975 (Cth), there was a subsequent increase in second marriages and step-children. Together with the growing number of de facto relationships, the narrow terms of the statute led to many cases of injustice in the latter part of the $20^{\text {th }}$ century. These facts are recognised in the Second Reading Speeches of the Wills Bill 1997 (Vic) ${ }^{9}$ as leading to the reform. The 1997 reforms removed the statutory list of eligible applicants and replaced it with section 91(4)(a), which posed a new 'jurisdictional question' of whether or not the deceased

\footnotetext{
${ }^{3}$ Widows and Young Children Maintenance Act 1906 (Vic).

${ }^{4}$ Administration and Probate Act 1958 (Vic) s 91, as repealed by Wills Act 1997 (Vic) s 55.

${ }^{5}$ (Unreported, Supreme Court of Victoria, Nathan J, 14 February 1997).

${ }^{6}$ Coombes v Ward [2004] VSCA 51 (4 March 2004) [3].

${ }^{7}$ Rowe v Popple (Unreported, Supreme Court of Victoria, Nathan J, 14 February 1997) [24].

${ }^{8}$ Popple v Rowe [1998] 1 VR 651, 655-7.

${ }^{9}$ Parliament of Victoria, Hansard, Legislative Assembly, 9 October 1997, 433, 436 (Hon Jan Wade); Parliament of Victoria, Hansard, Legislative Council, 12 November 1997, 447, 44950 (Hon Louise Asher).
} 
had a 'responsibility' to provide for the applicant. ${ }^{10}$ Under the new provisions, the court is directed to consider a list of factors contained in sections 91(4)(e)-(p) in coming to its decision, with family or 'other relationship' contained in section 91(4)(e). Since, under these provisions, in effect 'anyone' can claim, questions arise regarding the type of relationship between the deceased and the applicant that is required as the basis of a successful claim.

Fourteen years after the reforms were introduced, the Act is again the subject of an inquiry - the Inquiry into Succession Law by the Victorian Law Reform Commission ('VLRC'), which questions whether eligibility to apply should once again be restricted, and whether all costs of the proceeding should continue to be paid out of the estate. ${ }^{11}$

This article examines the history of the provisions and the approach the courts have taken in deciding claims, before analysing a selection of judgments that show the range of applicants who are currently eligible to apply. The concerns of the VLRC will then be addressed.

\section{The History of the Provisions}

Family provision originated in New Zealand in 1900 with the Testator's Family Maintenance Act 1900 (NZ). Victoria was the first Australian jurisdiction to adopt family provision in the form of the Widows and Young Children Maintenance Act 1906 (Vic). Family provision developed as a response to men refusing to make testamentary provision for their wives and children, following the abolition of 'dower' - the legal right of a widow to inherit land from the estate of her husband for the purpose of supporting herself after his death. Dower had been abolished because it was a legal right that attached to the land, rather than being held by the widow personally, and as such created conveyancing difficulties for subsequent owners. ${ }^{12}$ Following its abolition, a widow was left with an 'expectation without right' ${ }^{\text {,13 }}$ that her husband would make appropriate provision.

New Zealand was a leader in law reform among common law countries during the latter part of the $19^{\text {th }}$ century, and introduced many progressive laws in

\footnotetext{
${ }^{10}$ Schmidt $v$ Watkins [2002] VSC 273 (24 July 2002) [6]-[11].

${ }^{11}$ VLRC, Terms of Reference - Succession Law (2012).

${ }^{12}$ Rosalind F Atherton, 'Expectation without Right: Testamentary Freedom and the Position of Women in $19^{\text {th }}$ Century New South Wales' (1998) 11 University Of New South Wales Law Journal 133, 148-9.

${ }^{13}$ Ibid 154.
} 
response to the agitation for women's rights. Testators' family maintenance can be seen as an important feminist achievement. ${ }^{14}$ Lady Anna and Sir Robert Stout were the leaders of the movement towards better family maintenance in New Zealand. Sir Robert originally sought to introduce a 'set shares' scheme, whereby dependants of the deceased were entitled to a set share of the estate, similar to what exists today in many civil law countries. ${ }^{15}$ However, bills introduced by Stout in 1896 and 1897 failed to pass through Parliament. Atherton has observed that this was not surprising, given the liberal climate in New Zealand in the late 1800s and the attitude that state intervention in matters of private property rights was appropriate only on 'moral' grounds. ${ }^{16}$ The issues raised included whether property was in essence an 'individual right', or carried with it a social responsibility, that could be utilised as an instrument of control. ${ }^{17}$ Questions also arose in regard to whether an individual should be entitled to disinherit dependents, leaving the state to support them, and whether the character and conduct of the applicant was at all relevant. ${ }^{18}$ Stout resigned from Parliament in 1898 and became the first Chief Justice of the Supreme Court of New Zealand, delivering a number of judgments that are still cited today, and that provide core family provision principles. $^{19}$

Robert McNab continued the cause, with one important difference - he advocated a shift away from set shares to complete freedom of testation, subject to the right of a dependant to apply for an order if that person was left without proper provision. This was the polar opposite of Stout's proposal, but it achieved the same object of ensuring provision for those to whom the deceased owed a responsibility, ${ }^{20}$ while also allowing a testator to disinherit

\footnotetext{
${ }^{14}$ Ibid 154-6.

${ }^{15}$ See, eg, Wilbert D Kolkman, 'Freedom of Testation in the Netherlands' in Reinhard Zimmermann (ed), Freedom of Testation (Mohn Siebeck, 2012) 32-5. The Dutch Civil Code provides direct descendants of the deceased with the statutory right to a set share of the estate, regardless of what other gifts the descendant may have received. Until 2003, in the Netherlands, the 'statutory heir' was entitled to an actual share of the estate, but now is entitled only to pursue a monetary claim. Kolkman notes that an 'overwhelming majority' of commentators are of the view that this system is an unjustified restriction of the freedom of testation.

${ }^{16}$ Rosalind Atherton, 'New Zealand's Testator's Family Maintenance Act of 1900 - the Stouts, the Women's Movement and Political Compromise' (1990) 7(2) Otago Law Review 202, 212.

${ }^{17}$ Rosalind Atherton, 'The Concept of Moral Duty in the Law of Family Provision - a Gloss or Critical Understanding?’ (1999) 5 Australian Journal of Legal History 5, 8.

${ }^{18}$ Atherton, 'New Zealand's Testator's Family Maintenance Act of 1900', above n 16, $216-7$.

${ }^{19}$ See, eg, Allardice v Allardice (1910) 29 NZLR 959 (NZCA); Allen v Manchester [1922] NZLR 218 (NZSC).

${ }^{20}$ Atherton, ‘New Zealand's Testator’s Family Maintenance Act of 1900’, above n 16, 202-15.
} 
an applicant of whose character and conduct the testator disapproved. ${ }^{21}$ This has been seen as a 'brilliant political compromise', ${ }^{22}$ and in 1900 the bill that would become the Testator's Family Maintenance Act was finally passed. The Act consisted of a single page. It gave the Supreme Court of New Zealand the discretion to order such provision out of the estate as it deemed fit, provided that the applicants' character or conduct did not disentitle them. Application could be made by the wife, husband or children of the deceased, who had been left without 'adequate' provision for their 'proper' maintenance and support. ${ }^{23}$ No further guidance was given to the court, which therefore had to determine the correct application of the Act according to its purpose and object.

Analysing the early cases in New Zealand, Atherton observes that the wording of the Act, using two different terms, 'adequate' and 'proper', implied that there must be a difference between them. 'Adequate' would seem to be an objective, economic test, while 'proper' would seem to invite more subjective criteria, such as the relative size of the estate, and the lifestyle that the deceased had allowed the claimant to become accustomed to. ${ }^{24}$ Importantly, the court only had jurisdiction to provide 'proper' provision, not to engage in a complete re-write of the will of the testator. ${ }^{25}$ The task of the court, then, was to find the 'dividing line' between making proper provision, and impinging upon the deceased's freedom of testation. ${ }^{26}$ Atherton comes to the conclusion that the existence of subjective criteria that directed the court to take all the circumstances of the case into account implied that there was some sort of 'moral obligation' upon individuals to use their freedom of testation in a certain way. Adding weight to this idea, the freedom of testation at various times has been seen as a means of social control. Under a set shares regime, all children of a family will inherit wealth, regardless of the child's effort in life, whereas freedom of testation means that a father may reward his hardest working children. This is in turn fosters the economic growth of the state. ${ }^{27}$ It was the abuse of this control that led to the introduction of this legislation. The object and purpose of the Act 'was not merely, or even primarily, concerned with relieving the state of the financial burden of supporting indigent widows and children. The courts were not empowered merely to make such provision for an applicant as would rescue the applicant

\footnotetext{
${ }^{21}$ Ibid 220.

${ }^{22}$ Ibid 214.

${ }^{23}$ Testator's Family Maintenance Act 1900 (NZ) s 2.

${ }^{24}$ Atherton, 'The Concept of Moral Duty in the Law of Family Provision', above n 17, 10.

${ }^{25}$ Ibid 11-12 citing Allardice v Allardice (1910) 29 NZLR 959, 969.

${ }^{26}$ Atherton, 'The Concept of Moral Duty in the Law of Family Provision', above n 17, 12.

${ }^{27}$ Ibid 18-9.
} 
from destitution'. ${ }^{28}$ Rather, the court was given the power to enforce the moral duty of the deceased to use the freedom of testation to make 'adequate provision' for the 'proper maintenance and support' of those to whom they owed a responsibility.

\section{The APPROACH OF THE COURT}

The first version of the Victorian provisions in the Widows and Young Children Maintenance Act were modelled on the New Zealand provisions, and the Supreme Court of Victoria has always followed the 'moral duty' approach developed in the New Zealand Supreme Court.

Under Part IV of the Administration and Probate Act 1958 (Vic), section 91(4) poses what are commonly referred to as the 'three jurisdictional questions': ${ }^{29}$

(1) Whether or not the deceased had a responsibility to make provision for the applicant;

(2) Whether or not the distribution of the estate as effected by the deceased's will, or the operation of the intestacy provisions, or both, makes adequate provision for the proper maintenance and support of the applicant; and

(3) The amount of provision (if any) which the court may order for the applicant.

In applying all three jurisdictional questions, the court must have regard to factors listed in sections 91(4)(e)-(p). These factors include family or other relationships; the obligations or responsibilities of the deceased person to the applicant or any other person; the size and nature of the estate; the financial resources and needs of the applicant; any physical, mental or intellectual disability of the applicant; the applicant's age; any contribution made by the applicant to building up the estate, or to the welfare of the deceased, for which no adequate consideration was given; any benefits previously given to the applicant by the deceased; whether the applicant was being maintained by the deceased before that person's death, and on what basis this responsibility was assumed; the liability of any other person to maintain the applicant; the character and conduct of the applicant towards the deceased; and any other

\footnotetext{
${ }^{28}$ Vigolo v Bostin (2005) 221 CLR 191, 199-200.

${ }^{29}$ Blore v Lang (1960) 104 CLR 124, 128; Administration and Probate Act 1958 (Vic) ss 91(4)(a)-(c).
} 
matter the court considers relevant. These factors are essentially a codification of 'all the circumstances of the case' that were considered under the preamendment common law. ${ }^{30}$ However:

[s]elf-evidently, such matters [are] of themselves incapable of providing an answer to [the jurisdictional questions]. To reason from the matters mentioned in [sections 91(4)(e)-(p)] to a conclusion that a testator had a responsibility to make provision for a claimant, or that the testator failed to make adequate provision for the claimant, necessitate[s] the application of a test or standard to the matters to be considered. That test remain[s] one of whether and if so what provision a wise and just testator would have thought it his moral duty to make in the interests of the claimant. ${ }^{31}$

Despite this being long established in succession law, there has been criticism from the High Court of Australia regarding the intrusion of the term 'moral duty' upon the words of the statute. ${ }^{32}$ However, the High Court reversed its position of discouraging reference to the deceased's 'moral duty' in the 2005 decision in Vigolo $v$ Bostin, ${ }^{33}$ which is the most recent family provision judgment from any jurisdiction. ${ }^{34}$ In Victoria, there is no uncertainty regarding the use of 'moral duty' to provide meaning to the words of the legislation. $^{35}$

In interpreting jurisdictional question one:

The question to be determined, in the words of the statute, is whether or not the deceased had responsibility to make provision for the applicant. That must mean a legal or moral responsibility, in the sense in which 'moral' has been explained in the authorities, for what other kind of responsibility is there ${ }^{36}$

\footnotetext{
${ }^{30}$ Richard v AXA Trustees Ltd [2000] VSC 341 (1 September 2000) [7].

${ }^{31}$ Blair v Blair (2004) 10 VR 69, 84 citing Collicoat v McMillan [1999] 3 VR 803, 815.

${ }^{32}$ Coates v National Trustees Executors \& Agency Co Ltd (1956) 95 CLR 494, 512-3, 522-3; Hughes v National Trustees Executors \& Agency Co of Australasia Ltd (1979) 143 CLR 134, 158-60; Goodman v Windeyer (1980) 144 CLR 490, 504-5; Singer v Berghouse (1994) 181 CLR 201, 209.

33 (2005) 221 CLR 191, 199-200, 204-5 (Gleeson CJ), 203 (Callinan and Heydon JJ); cf 214-7 (Gummow and Hayne JJ).

${ }^{34}$ See also Ellis v Foley [2009] HCATrans 143 (19 June 2009), an unsuccessful application for special leave to appeal from the New South Wales Court of Appeal. Note the exchange between Gummow J and counsel for the applicant regarding Singer $v$ Berghouse (1994) 181 CLR 201 and Vigolo $v$ Bostin (2005) 221 CLR 191.

${ }^{35}$ Collicoat v McMillan [1999] 3 VR 803, 815-20; Grey v Harrison [1997] 2 VR 359, 361, 365; Blair v Blair (2004) 10 VR 69, 84.

${ }^{36}$ Lee v Hearn (2005) 11 VR 270, 273.
} 
In the course of interpretation of jurisdictional question two:

It has often been pointed out that very important words in the statute are 'adequate provision for the proper maintenance and support' and that each of these words must be given its value. 'Adequate' and 'proper' in particular must be considered as words which must always be relative. The 'proper' maintenance and support of a son claiming a statutory provision must be relative to his age, sex, condition and mode of life and situation generally. What is 'adequate' must be relative not only to his needs but to his own capacity and resources for meeting them. There is then a relation to be considered between these matters on the one hand, and on the other, the nature, extent and character of the estate and the other demands upon it, and also what the testator regarded as superior claims or preferable dispositions. The words 'proper maintenance and support', although they must be treated as elastic, cannot be pressed beyond their fair meaning. ${ }^{37}$

Adequate provision is something more than bare subsistence - it is not just provision 'for the bread and butter of life, but for a little of the cheese or jam'. ${ }^{38}$ It is 'something more than a provision to keep the wolf from the door - it should at least be sufficient to keep the wolf from pattering round the house or lurking in some outhouse in the back yard'. ${ }^{39}$ Meeting all of the applicant's needs is not necessarily proper, and proper is not necessarily defined by reference to the mode of life experienced by the applicant during the lifetime of the deceased, whether it was generous or mean. ${ }^{40}$ The applicant does not need to be completely unable to support him- or herself to satisfy jurisdictional question two, and the court does not expect applicants to exhaust their own resources before being eligible to receive provision. ${ }^{41}$ On the other hand, being left with no provision at all does not automatically lead to a finding of the provision being improper. ${ }^{42}$ Adequate provision for proper maintenance and support is relative to all the circumstances of the case.

In considering jurisdictional question three, '[t]he Court is given not only a discretion as to the nature and amount of the provision it directs but, what is even more important, a discretion as to making a provision at all'. ${ }^{43}$ That is, while an applicant may have established that the deceased had a responsibility to provide for the applicant (question one), and that the applicant has been left

37 Pontifical Society for the Propagation of The Faith $v$ Scales (1962) 107 CLR 9, 19 (Dixon CJ) ('Pontifical Society').

${ }^{38}$ Blore v Lang (1960) 104 CLR 124, 135.

${ }^{39}$ King $v$ White [1992] 2 VR 417, 425 citing Re Harris (Deceased) (1936) SASR 497, 501.

${ }^{40}$ Allen v Manchester [1922] NZLR 218, 222; Re Buckland (Deceased) [1966] VR 404, 412-3.

${ }^{41}$ Re Buckland (Deceased) [1966] VR 404, 416.

${ }^{42}$ Allen $v$ Manchester [1922] NZLR 218, 221-2.

${ }^{43}$ Pontifical Society (1962) 107 CLR 9, 19. 
without adequate provision for his or her proper maintenance and support (question two), the court may nevertheless refuse to make an order for provision (in responding to question three). This is usually due to the fact that another person to whom the deceased owed a 'responsibility' has a stronger claim, and the estate is not sufficient to fund both. In formulating an order for provision, the court approaches the task by asking what provision the deceased 'would have thought it his moral duty to make ... had he been fully aware of all the relevant circumstances', 44 and treating the deceased as 'wise and just, rather than a fond and foolish' testator. ${ }^{45}$ The court may order only that which is adequate to provide proper maintenance and support, and does not have a general licence to re-write the will of the deceased in accordance with its own ideas of fairness. ${ }^{46}$ The court may encroach on the deceased's freedom of testation only so far as to fulfil the testator's moral duty to make provision: 'A breach of moral duty is the justification for curial intervention and simultaneously limits its legitimate extent. ${ }^{47}$

In reviewing past cases it is to be observed that courts have established a consistent approach. Typically, the court has: stated the moral duty test; reminded itself that jurisdiction is restrained by the freedom of testation; then set out section 91 in full, using each paragraph of sub-sections (4)(e)-(p) as sub-headings under which the judge has stated his or her findings on the evidence, before concluding whether the three jurisdictional questions have been satisfied, and whether an order should be made. ${ }^{48}$ Some judges, however, have simply stated that they have considered 'all the circumstances of the case' in accordance with the moral duty of the deceased to make adequate provision for proper maintenance and support of those to whom they owe a responsibility, before stating what the judge found to be the most cogent reasons to grant or refuse an order. Despite the wide variance in judgment length (some are only a few pages, others over 100), for each claim, a judge must undertake 'an instinctive synthesis that takes into account all the relevant factors and gives them due weight'. ${ }^{49}$ It is not a scientific or arithmetic exercise, and 'minds may legitimately differ as to the provision which should be made'. ${ }^{50}$ The exercise has been compared to sentencing a criminal offender, ${ }^{51}$ or making an assessment of damages in a personal

\footnotetext{
${ }^{44}$ Allen v Manchester [1922] NZLR 218, 220-1; Allardice v Allardice (1910) 29 NZLR 959, 972-3.

${ }^{45}$ Bosch v Perpetual Trustees Co (Ltd) [1938] AC 463 (UKPC), 479.

${ }^{46}$ Worladge v Doddridge (1957) 97 CLR 1, 20-1.

${ }^{47}$ Grey v Harrison [1997] 2 VR 359, 366.

${ }^{48}$ See, eg, Scarlett v Scarlett (2012) 7 ASTLR 397.

${ }^{49}$ Grey v Harrison [1997] 2 VR 359, 367.

${ }^{50}$ White v Muldoon [2006] VSC 204 (8 June 2006) [72].

${ }^{51}$ Grey v Harrison [1997] 2 VR 359, 367.
} 
injuries case. ${ }^{52}$ This means that judgments are very fact specific, and there is little to be gained from making comparisons of the quantum of orders in different cases. However, this does not mean that it is impossible to predict the outcome of a claim.

The next part of the article will examine a selection of judgments that feature applicants with different types of relationship to the deceased, with the aim of identifying the particular features and nature of relationship required for success in each category of claim.

\section{WIDOWS AND WIDOWERS}

In an early case heard under the new provisions, Harper $\mathrm{J}$ considered the character of a relationship that will give rise to a finding of moral duty to provide. Considering the terms of the Statute Law Amendment Relationships Act 2001 (Vic) a helpful analogy, Harper J held that:

Generally speaking ... a 'domestic [relationship] where there is mutual commitment to an intimate personal relationship and shared life as a couple, irrespective of the gender of each partner' would be sufficient to bring either one of those partners within the class of persons to whom the other had responsibility. ${ }^{53}$

However, the starting point is not that the court must make a positive finding of the existence of a 'domestic relationship', as defined in the Relationships Act 2008 (Vic). ${ }^{54}$ There is no requirement that the applicant and deceased should have been in a long-term exclusive relationship of mutual support to establish 'responsibility' to provide. ${ }^{55}$ Regardless of the status of their relationship, if applicants are capable of supporting themselves, then the fact that the deceased had assumed responsibility for them in the past will not automatically 'impose an obligation upon .... [the] estate to in effect entirely support ... [them] for the remainder of ... [their] life'. ${ }^{56}$ However, when a

\footnotetext{
${ }^{52}$ Singer v Berghouse (1994) 181 CLR 201, 211.

${ }^{53}$ Schmidt $v$ Watkins [2002] VSC 273 (24 July 2002) [22] quoting Statute Law Amendment Relationships Act 2001 (Vic) s 1(2).

${ }^{54}$ Allen v Huntley [2011] VSC 175 (15 April 2011) [75]; Relationships Act 2008 (Vic) s 5: A 'registrable domestic relationship' is '[a] relationship ... between two adult persons who are not married to each other but are a couple where one or each of the persons in the relationship provides personal or financial commitment and support of a domestic nature for the material benefit of the other, irrespective of their genders and whether or not they are living under the same roof'.

${ }^{55}$ Estrella v McDonald [2012] VSC 62 (26 February 2012).

${ }^{56}$ White v Hannover [2010] VSC 577 (10 December 2010) [77].
} 
moral duty is established, it is 'generally recognised that a widow [or widower] has a higher moral claim on the estate than anybody else, ${ }^{57}$ and 'where the estate is of considerable value, and there are no competing claims of children, [it] should not be disposed of in any niggardly manner' ${ }^{58}$

The case of Whitehead $v$ State Trustees $L t d^{59}$ provides an example of a successful application, where provision was ordered for the partner of the deceased and her nine-year-old son. The applicant had fallen pregnant with her son before commencing a relationship with the deceased, who encouraged her to continue with the pregnancy, and promised to look after both mother and child. ${ }^{60}$ The deceased was an elderly man who had always lived alone, and his family did not believe that he was in a relationship with the applicant. Despite the fact that the applicant and the deceased did not share a conventional husband/wife relationship, and the deceased was not responsible for the day to day care of her son, Bell $\mathrm{J}$ found that their relationship 'represented a social unit which was tantamount to a family', ${ }^{61}$ and that the deceased's father-son relationship with the child was an 'extremely important relationship' for him. ${ }^{62}$ From the $\$ 2.1$ million estate, the applicant received a legacy of $\$ 450000$, and her son received a legacy of $\$ 400000$. In affirming this decision on appeal, Neave JA held that:

Family relationships have become increasingly diverse. Changes in the law have resulted in ties based on affection, rather than formal legal status, receiving greater recognition for a variety of legal purposes. Part IV itself recognises that a person may have a moral duty to provide for the maintenance and support of another person, even in the absence of a de jure marriage or a de facto relationship, or a parent/child relationship. A man and a woman [or a same sex couple] may have an emotional commitment to each other akin to that of family members, even if they do not live together. Such a commitment may exist even though the parties are not financially dependent on one another and neither party contributes to the building up of the other parties' [sic] property. The scope of Part IV is not confined to those in relationships which do not conform to traditional ideas about male/female and parent/child relationships. ${ }^{63}$

\footnotetext{
${ }^{57}$ King $v$ White [1992] 2 VR 417, 423.

${ }^{58}$ Worladge $v$ Doddridge (1957) 97 CLR 1, 11.

${ }^{59}$ (2011) 4 ASTLR 528.

${ }^{60}$ Ibid 580 [330], affd State Trustees Ltd v Bedford [2012] VSCA 274 (16 November 2012).

${ }^{61}$ Whitehead v State Trustees Ltd (2011) 4 ASTLR 528, 568 [218].

${ }^{62}$ Ibid 580 [330].

${ }^{63}$ State Trustees Ltd v Whitehead [2012] VSCA 274 [130]-[131].
} 
An example of an unsuccessful claim is given in the case of Bentley $v$ Brennan. ${ }^{64}$ The deceased was a much older man who had sexually abused the applicant throughout his childhood and adolescence, with the relationship resuming consensually when the applicant was a young adult. The applicant had suffered many mental health problems as a result of the abuse. He later married and had children, but the marriage was not successful. Byrne $\mathrm{J}$ found that the applicant 'retained a great affection for the deceased but they did not enjoy anything like a domestic partnership. It may well be that the older man shared his affections with persons other than the plaintiff, and there is no evidence as to how he saw the relationship between himself and the plaintiff' ${ }^{65}$ Byrne J explained,

I would liken this relationship to be akin to that between a man and a close woman friend. I do not refer to the image of a man with a kept mistress or even of a man who engaged in intermittent dalliance with a woman; the relationship here was based on a close and loving friendship with an underlying sexual element which surfaced from time to time. ${ }^{66}$

Regarding the abuse, Byrne $\mathrm{J}$ pointed to the purpose of the Act and commented that while '[i]t may be that the general community would applaud [a decision of the deceased] to make provision in his will for such a person by way of atonement ... [the imposition of such a provision] is not the role of Part 4 of the Administration and Probate Act' ${ }^{67}$

\section{INFANT CHILDREN}

There is usually no problem with an infant child or step-child of the deceased establishing that the deceased had a responsibility to provide for that child. In addition, an adopted child, ${ }^{68}$ or child conceived with the assistance of reproductive technology ${ }^{69}$ is considered to have the same status as a biological child of the deceased, and this factor does not diminish the strength of their claim. A foster child who has been raised by the deceased as his or her own child, without being legally adopted, has also been successful in making a family provision claim. ${ }^{70}$ However, a practical consideration in other family provision claims may be that the needs of the foster child are being met by the

\footnotetext{
${ }^{64}$ [2006] VSC 113 (7 April 2006).

${ }^{65}$ Ibid [18].

${ }^{66}$ Ibid [27]. See also Larkin v Borg [2013] VSC 128 (12 April 2013).

${ }^{67}$ Bentley v Brennan [2006] VSC 113 (7 April 2006) [31].

${ }^{68}$ Adoption Act 1984 (Vic) s 53; see also Dehnert v Perpetua1 Executors \& Trustees Association of Australia Ltd (1954) 91 CLR 177; Hv T [1975] VR 47.

${ }^{69}$ Status of Children Act 1974 (Vic) pt II.

${ }^{70}$ Sellers v Hyde [2005] VSC 382 (27 September 2005).
} 
child's new foster carer. This issue arose in a family provision claim by an applicant who was the natural child of the deceased, and had been surrendered for adoption, although remaining in contact with the parent. While the fact that the applicant was the child of the deceased was important, the relevant question was the 'nature' of the relationship, ${ }^{71}$ that is, whether it was one in which the deceased had a moral duty to provide adequate and proper support, in all the circumstances of the case.

The focus of debate in applications concerning children that go to trial is usually the amount of the order for provision, or what financial needs of the child it should cover. It may be difficult to estimate the needs of very young children when formulating an order, but there is no reason why provision cannot be ordered that stretches well into their future. ${ }^{72}$ The needs of an infant child may include being 'maintained, housed, clothed, fed, educated and ... provided with reasonable recreation, entertainment and any necessary medical care' ${ }^{73}$ An example of a generous order is to be found in Whitehead $v$ State Trustees $L t d{ }^{74}$ where Bell $\mathrm{J}$ made provision for a nine-year-old child, whose mother was in a relationship with the deceased, to receive support from the estate until he was 18 years old, then a car, payment of tertiary education fees, and a deposit on a home. Orders usually do not include an education at a feepaying private school, which is properly characterised as a 'privilege'. ${ }^{75}$ In some circumstances, however, such an education may be appropriate if the applicant can establish a special need, for example where the applicant suffers from learning difficulties. ${ }^{76}$

\section{Adult ChiLdRen}

In the very early cases, the court was hesitant to grant the claim of an adult son. Stout CJ in Allardice $v$ Allardice commented that '[i]f they had any push they should, considering their age, have ere this done something for themselves, and to settle money on them now might destroy their energy and weaken their desire to exert themselves'. ${ }^{77}$ Conversely, the claims of adult daughters, including those who were married, were usually granted. While there has been great social change, and the gender of the applicant is no

\footnotetext{
${ }^{71}$ Coombs v Ward [2002] VSC 61, 64-5.

${ }^{72}$ Blore v Lang (1960) 104 CLR 124, 128.

${ }^{73}$ MacEwan Shaw v Shaw (2003) 11 VR 95, 184.

${ }^{74}$ (2011) 4 ASTLR 528, 581 [341], affd State Trustees Ltd v Bedford [2012] VSCA 274 (16 November 2012). See also Borebor v Keane [2013] VSC 35 (19 February 2013).

${ }^{75}$ MacEwan Shaw v Shaw (2003) 11 VR 95, 121.

${ }^{76}$ Suffern v Suffern-Noble [2002] VSC 389 (11 September 2002) [35], [62].

${ }^{77}$ Allardice v Allardice (1910) 29 NZLR 959, 971.
} 
longer a specific factor to be considered, ${ }^{78}$ the early principles concerning adult children provide useful guidance in the modern cases: '[w]hile Part IV as amended has introduced greater flexibility, it does not represent a radical break with the principles recognised in previous authorities. ${ }^{79}$

Fullagar J developed the 'special need' or 'special claim' approach for claims by adult sons:

No special principle is to be applied in the case of an adult son. But the approach of the Court must be different. In the case of a widow or an infant child, the Court is dealing with one who is primâ facie dependent on the testator and primâ facie has a claim to be maintained and supported. But an adult son is, I think, primâ facie able to 'maintain and support' himself, and some special need or some special claim must, generally speaking, be shown to justify intervention by the Court under the Act. (It is perhaps necessary to add that in using the word 'adult' and the word 'infant' I am not thinking of a hard and fast boundary line fixed conclusively on the attainment of 21 years. $)^{80}$

A 'special need' or 'special claim' may arise in a variety of ways:

In some cases a special claim may be found to exist because the applicant has contributed to building up the testator's estate or has helped him in other ways. In other cases a son who has done nothing for his parents may have a special need. This may be because he suffers from some physical or mental infirmity, but it is not necessary for an adult son to show that his earning powers have been impaired by some disability before he can establish a special need for maintenance or support. He may have suffered a financial disaster; he may be unable to obtain employment; he may have a number of dependants who rely on him for support which he cannot adequately provide from his own resources. There are no rigid rules; the question whether adequate provision has been made for the proper maintenance and support of the adult son must depend on all the circumstances - that is, on all the facts that existed at the date of the death of the testator, whether the testator knew of them or not, and all the eventualities that might at that date reasonably have been foreseen by a testator who knew the facts. ${ }^{81}$

\footnotetext{
${ }^{78}$ Allan v Allan [2001] VSC 242 (25 July 2001) [63]-[67].

${ }^{79}$ De Angelis v De Angelis [2003] VSC 432 (10 November 2003) [113].

${ }^{80}$ Re Sinnott (Deceased) [1948] VLR 279, 280-1.

${ }^{81}$ Hughes $v$ National Trustees Executors \& Agency Co of Australia Ltd (1979) 143 CLR 134, 147-8.
} 
A modern application of these principles is found in Anderson $v$ Teboneras. ${ }^{82}$ A 22-year-old adult son was found to have a special claim arising from working in the deceased's hairdressing salon without proper remuneration, and a special need was established due to his 'youth, inexperience in business and his financial vulnerability as a recently married man'. ${ }^{83}$ An application heard under the current provisions is found in Blair $v$ Blair, ${ }^{84}$ which considered the claim of an able-bodied and self-supporting adult son who had received a legacy of $\$ 150000$. The defendant was his brother, who had received the remainder of the $\$ 700000$ estate, which consisted of the family farm. Both sons had worked on the farm, but the applicant decided to leave and become a vet, establishing his own practice. Harper J ordered provision for the applicant on the basis of the disparity in the position of the brothers, the defendant being much better placed due to the 'head start' in life he had been given by his father, while the applicant had received no assistance. ${ }^{85}$

While the claims of adult daughters are no longer so readily granted,

[o]ne should ... be cautious about suggesting that because of changes in community views, the courts should now be less generous in relation to claims by daughters. More often than not claims coming before the courts have been brought by middle-aged children against the estates of parents who have died in their 60s, 70s or 80s. Many years have passed since those children were brought up by their parents, trained for life as best they could be and launched into a very different adult world ... Consequently, even 30 to 40 years later when opportunities may appear to be greater and expectations certainly are, one is nevertheless still dealing with applications such as these, brought by applicants whose lives have been largely moulded many years in the past and whose opportunities were, in some senses, restricted by that upbringing. Their moral claims and, more importantly, the correlative moral obligation of their parents must reflect that background and cannot be ignored in ascertaining what is adequate for their proper maintenance and support. ${ }^{86}$

An example is given in Woods $v$ Stevenson, Nathan $\mathrm{J}$ finding in that case that two adult daughters had 'endured debilitating and unsatisfactory first marriages. Both [were] now impoverished and almost without assets' ${ }^{87}$ Both daughters received an increase in their share of the estate. However, it has also been held that an applicant must be able to show that his or her need

\footnotetext{
${ }^{82}$ [1990] VR 527.

${ }^{83}$ Anderson v Teboneras [1990] VR 527, 541.

${ }^{84}$ [2002] VSC 95 (4 April 2002), affd Blair v Blair (2004) 10 VR 69.

${ }^{85}$ Blair v Blair [2002] VSC 95, [89]-[91].

${ }^{86}$ Collicoat v McMillan [1999] 3 VR 803, 823.

${ }^{87}$ Woods v Stevenson [2003] VSC 498 (19 December 2003) [10].
} 
outweighs that of the other beneficiaries of the estate, who may be the applicant's siblings and in a similar financial situation. ${ }^{88}$

A common scenario that leads to claims by adult children is that of the applicant having worked in a family business or on a family farm. In Anderson $v$ Teboneras, ${ }^{89}$ the applicant's claim was supported by the fact that he was young and inexperienced in business, and the deceased had made all the executive decisions; while in Blair $v$ Blair, the deceased had left virtually the entire estate, the family farm, to one beneficiary, while the applicant, his brother, had struggled to build his own veterinary practice from scratch. In both these cases the applicants were successful. It may also be necessary to make a claim due to the practical effect of the provisions of the will on the ability to operate the family business. The VLRC has recognised this issue. ${ }^{90}$ For example, in Walker $v$ Walker, ${ }^{91}$ an application for leave to bring a claim out of time was made by an adult son who ran the family farm. The deceased had divided his parcels of land between all four of his children. The applicant successfully argued that 'the difficulty with these dispositions is that my father has thereby made it financially impossible for me to carry on the family business', since it would be necessary for the applicant to buy out his siblings in order to facilitate the proper operation of the farm. Another example is Vincent $v$ Rae, ${ }^{92}$ where Hansen $\mathrm{J}$ again noted the adverse effect on the operation of a farm if the legal ownership of the land were divided up. In Torney $v$ Shalders, ${ }^{93}$ Mandie J held that the deceased had 'a general obligation that arose in all the circumstances, to satisfy, so far as possible, the reasonable expectation of [the adult son] to inherit a farming business and a number of farming properties upon which to conduct that business'. When claims are granted that affect a family business, a judge must take great care that the order does not disrupt the continuation of the business, ${ }^{94}$ for example by providing the owner with the option to choose how an order for provision is funded out of the estate.

It is easy to understand the logic behind the claims of adult children who have made non-financial contributions to a family business or family farm, or who have suffered a 'disaster' of some sort, such as the early death of a spouse, injury or bankruptcy. It is harder to see why an able-bodied adult child, who is

\footnotetext{
${ }^{88}$ Gapes v Haeberle [2003] VSC 461 (21 October 2003) [32].

${ }^{89}$ [1990] VR 527.

${ }^{90}$ VLRC, Family Provision, Consultation Paper No 12 (2013) 24 [2.34]-[2.37] ('VLRC 2013

Family Provision Paper').

91 [2004] VSC 94 (29 March 2004) [9].

92 [2006] VSC 346 (22 September 2006) [86].

${ }^{93}$ [2009] VSC 268 (3 July 2009) [63].

${ }^{94}$ See, eg, Collicoat v McMillan [1999] 3 VR 803, 831-2.
} 
not financially dependent on the deceased and has not been for some time, should be granted provision. In fact, actual financial dependency has never been the relevant test under the Act. Rather, the test concerns whether a moral duty exists to provide for an applicant who is in relative need, according to all the circumstances of the case. This may be established if an adult child has a high amount of debt, children to provide for, and little in the way of savings, with no prospects of being able to build up sufficient superannuation to provide for themselves and their dependants into old age. An order for provision 'would make a world of difference to [their] comfort and happiness'. 95

\section{AdULt STEP-CHILDREN}

In many step-child cases, the relationship between the applicant and the deceased tends to be based solely on the relationship between the deceased and the child's natural parent. There is no need to show that there was a substitute parent-child relationship between the applicant and the deceased. But if an applicant has had little contact with the deceased following the death of the applicant's natural parent, or if the three have never lived together as a family unit, then it may be difficult to establish that a moral duty existed. ${ }^{96}$ If the 'reality of the relationship' was that the applicant and deceased were 'in effect' parent and child, then the usual approach for adult children will apply. $^{97}$

An adult step-child who did not share a close relationship with the deceased will often be successful if it can be shown that the deceased's estate was derived from that of the natural parent, who has pre-deceased the testator. Nettle $\mathrm{J}$ held in McKenzie $v$ Topp $^{98}$ that

right thinking members of society are likely to accept that the needs of the widow of a second marriage should rank in priority ahead of the claims of the [adult] children of a first marriage; although of course it is always a question of fact. But equally, upon the death of the widow, and as it were in the event of a surplus, most would surely say that the children of the first marriage should rank for their fair share. For once the widow is gone, and therefore no longer in need of provision, her needs no longer warrant that the children rank behind her or thus her chosen successors.

\footnotetext{
${ }^{95}$ Re Sinnott (Deceased) [1948] VLR 279, 281.

${ }^{96}$ Henderson v Rowden [2001] VSC 267 (14 August 2001) [12]-[13], [22].

${ }^{97}$ Quinn v Robertson [2009] VSC 245 (10 June 2009) [20]-[23].

${ }^{98}$ [2004] VSC 90 (30 March 2004) [58].
} 
Balmford J applied the same reasoning in Keets $v$ Marks, ${ }^{99}$ and formulated the order for provision by reference to the amount that the deceased had inherited from his spouse.

\section{GRANDCHILDREN}

There is generally 'no moral obligation upon a [grandparent] to make provision for the maintenance and support of [a grandchild] simply by virtue of the existence of such a relationship. Such a moral obligation will rest upon the parents of a grandchild but not the grandparents'. ${ }^{100}$ The fact that a grandparent has made many generous gifts to a grandchild, or has financially assisted the child's parents, will not establish that the grandparent had a responsibility to provide. Nor will a promise to pay private school fees establish such a responsibility.

If the deceased grandparent has assumed the parental role, however, this is 'a strong prima facie indicator of a responsibility'. ${ }^{101}$ An example of a successful claim is the case of Subasa $v$ State Trustees Ltd. ${ }^{102}$ The applicant was the 'step-grandson' of the deceased, whose mother was the daughter of the deceased's second husband. The applicant never knew his father. When the applicant was five years old, his mother was placed into psychiatric care, and they never re-established a relationship. After living in a number of foster homes, he went to live with his grandparents, who treated him like a son. This was considered by the court to be a 'truly exceptional' ${ }^{\text {, }} 03$ case. Apart from the total assumption of care, an important factor in the success of this claim was that the defendant beneficiaries of the estate were distant relatives appointed under the intestacy provisions, with whom the deceased had no contact after migrating to Australia. 'Neither lived as if a child of the deceased., ${ }^{104}$

In most cases involving the estate of an individual who has grandchildren, it may be more appropriate for the parent of the grandchild, being the adult child of the deceased, to claim in that person's own right. As an adult child, the applicant may be able to establish responsibility by virtue of the parent-child relationship, and relative 'need' if the applicant can demonstrate an inability to meet all the expenses of raising young children, according to what is appropriate in all the circumstances of the case. Examples of relative need

\footnotetext{
${ }^{99}$ [2005] VSC 172 (20 May 2005) [22].

${ }^{100}$ Sherlock v Guest [1999] VSC 431 (12 November 1999) [25].

${ }^{101}$ MacEwan Shaw $v$ Shaw (2003) 11 VR 95, 120.

102 [2007] VSC 399 (12 October 2007).

${ }^{103}$ Ibid [42].

${ }^{104}$ Ibid [38].
} 
might include not being able to afford: a car with enough seats for the whole family; fees associated with children's sport, activities or hobbies; school camps and excursions; and a family holiday each year. If the estate is sufficient, then a testator has a moral duty to make provision for the parent of a grandchild to be able to meet these relative needs.

\section{Other Family Members of the Deceased}

Since the amended provisions came into force, there have been claims taken to trial by adult siblings of the deceased, nieces and nephews, a cousin and adult sons- or daughters-in-law. No data is available regarding claims that have settled, or been abandoned, and therefore the number of such claims is unclear. This is also the case where family provision claims have been brought by more distant relatives.

There are three approaches that may be utilised in family provision claims brought by non-linear family members. The first is to establish that the reality of the relationship between applicant and deceased is that of parent and child. For example, in Marshall $v$ Spillane, ${ }^{105}$ the deceased was the eldest sister in a family of six, and 21 years older than the applicant, who was her brother. The deceased had cared for the applicant since birth, and effectively raised him with her husband as their own child. In turn, when the deceased became frail, the applicant had cared for her in old age, as a 'dutiful son' would have done, establishing the responsibility to provide. ${ }^{106}$

The second approach is to establish that the applicant has cared for the deceased in the way that a child or spouse would, causing 'great disruption' to the applicant's own life. ${ }^{107}$ The applicant taking the deceased into his or her own home and caring for the deceased full time might establish this. The approach is not available when there is merely a close relationship between the two.

The third possibility is that the wealth of the deceased's estate has been derived from another deceased individual, with whom the applicant had a closer relationship. This approach has often been successful in claims by stepchildren, where a step-parent has inherited the bulk of the estate in question

\footnotetext{
${ }^{105}$ [2001] VSC 371 (28 September 2001).

${ }^{106}$ Ibid [15].

${ }^{107}$ McLeod v Troy [2002] VSC 187 (23 May 2002); Troy v Pyers [2002] VSC 188 (23 May 2002) (judgments delivered concurrently) [17]-[22]; cf James v Day [2004] VSC 290 (17 August 2004) [38].
} 
from the step-child's parent. ${ }^{108}$ It could also cover those situations where the estate has passed over another individual, from whom the applicant in due course would have inherited. An example is Petrucci $v$ Fields, ${ }^{109}$ which dealt with the claim of an adult daughter-in-law, who was the widow of the deceased's son. An earlier version of the deceased's will had provided that, if any of his children pre-deceased him, their share of his estate would go to their children. The deceased later changed his will, as he blamed the applicant for his son's death, which was in fact due to inoperable cancer. Mandie J thought that it was appropriate to order provision for the applicant and her children in these circumstances. ${ }^{110}$ A longer bow was drawn in Petersen $v$ Micevski, ${ }^{111}$ which dealt with the claims of two adult sisters to the estates of their sister and father, the father having died shortly after his daughter. The defendant was the deceased sister's twin sister. The deceased father and his wife had adopted the four women as children. It was proposed that the deceased sister had had responsibility to make provision for her siblings, as the main asset of her estate was a home, which had been paid for by their father and given to her. Theoretically, if their father had pre-deceased their sister, or not made this gift to her, then all four children would have shared in the estate. Hansen $\mathrm{J}$ accepted that this was a relevant consideration, but that it was not sufficient to justify an order that the deceased sister's estate be used to provide for her siblings. ${ }^{112}$ In the overall circumstances of the case, Hansen $\mathrm{J}$ found that the needs of the defendant were greater than that of the applicants, and dismissed the claim. ${ }^{113}$

The successful claims of non-linear family members demonstrate the importance of the test for eligibility in family provision claims remaining discretionary, rather than list-based. Despite the 'open category' of possible applicants, few claims have been taken to trial by individuals who did not have a close relationship with the deceased.

\section{Friends AND CARERS}

Perhaps the most controversial type of post-amendment family provision claim is that of the caring friend. There has been some confusion in practice regarding what type of relationship will lead to the required responsibility arising under the Act. A friend of the deceased will not be successful merely

\footnotetext{
${ }^{108}$ See, eg, McKenzie v Topp [2004] VSC 90 (30 March 2004).

${ }^{109}$ [2004] VSC 425 (29 October 2004).

${ }^{110}$ Ibid [61], [66].

${ }^{111}$ [2007] VSC 280 (14 August 2007).

112 Ibid [159].

${ }^{113}$ Ibid [162]-[163].
} 
because the friend has been living with the deceased, or has been provided with financial support, ${ }^{114}$ especially if 'the benefit of the arrangement was much more significant to the plaintiff than to the deceased'. ${ }^{115}$ While the fact that a person has acted as a carer, and thus contributed to the welfare of the deceased, and is a factor that the court is directed to consider under section $91(4)(k)$, that alone does not lead to a moral duty to provide.

[F]riends, neighbours and even mere acquaintances not infrequently provide to another assistance of an extraordinarily generous kind over an extraordinarily long period; but neither they, not the recipients of their generosity, nor the community, would necessarily or even ordinarily conclude that as a result the recipients had a responsibility to make adequate provision in their wills for the proper maintenance and support of their benefactors.

To state this conclusion is to draw attention to the object of the legislation. It is not to ensure that generosity is adequately rewarded or reciprocated. That, generally speaking at least, is a private matter. It is something for the individual conscience, not for the necessarily blunt instrument of the law. Rather, the object of the legislation is to ensure so far as the law can do it that those who have a duty not so much to reward but rather to provide maintenance and support do so by appropriate testamentary disposition. ${ }^{116}$

The leading example of a successful family provision application is Unger $v$ Sanchez. ${ }^{117}$ The applicant, who was the neighbour of the deceased, based her claim upon having cared for the deceased and her husband, and having formed a relationship such that the couple regarded her to be their 'adopted daughter'. ${ }^{118}$ It is very important to note that the deceased did not have any children, and the defendant beneficiary of the entire estate was a sister who lived in Spain. Kaye $\mathrm{J}$ thought that 'it would only be a rare and quite exceptional case which would justify a conclusion that the testator had a moral duty to provide for his or her maintenance and support'. ${ }^{119}$ The submissions of the applicant had placed special focus on the fact that her relationship with the deceased 'had a number of characteristics common to the relationship of a daughter to her mother'. ${ }^{120}$ The applicant gave 'an extraordinary degree of devotion and sacrifice ... The kind of devotion which she gave ... was at least equal to, if not well in excess of, the dedication which

\footnotetext{
${ }^{114}$ Lee v Hearn (2002) 7 VR 595, 597 (Warren J).

${ }^{115}$ Kolak v Morrell [2009] VCC 1171 (12 October 2009) [32].

${ }^{116}$ Schmidt $v$ Watkins [2002] VSC 273 (24 July 2002) [23]-[24].

${ }^{117}$ [2009] VSC 541 (1 December 2009).

${ }^{118}$ Ibid [3].

${ }^{119}$ Ibid [70].

${ }^{120}$ Ibid [72].
} 
might be expected of, and given by, an adult child to an ailing and ageing parent'. ${ }^{121}$ While the success of an application does not depend on relationship alone, Kaye $\mathrm{J}$ referred to the contribution that the applicant had made to the welfare of the deceased, and to the fact that '[i]n this respect, it is clear that the deserts of the plaintiff were particularly strong'. ${ }^{122}$ The fact that the applicant was not related to the deceased made her conduct all the more worthy. The applicant received \$200 000 from the \$1.5 million estate.

The VLRC has concerns about friends and carers making claims, and asks whether the current provisions are allowing speculative claims that executors must defend, thus depleting the assets of the estate.

\section{THE VICTORIAN LAW REFORM COMMISSION INQUIRY INTO SUCCESSION LAW}

The VLRC announced in March 2012 that it would be undertaking an inquiry into succession law. A series of Consultation Papers, ${ }^{123}$ along with a Short Information Paper on Costs Rules in Succession Proceedings, ${ }^{124}$ were released in December 2012 and the VLRC is to produce a final report by 1 September 2013. The terms of reference include family provision, wills, intestacy, the administration of estates and the regulation of legal practitioners acting as executors. The VLRC has been directed to examine whether the law is operating 'justly, fairly and in accordance with community expectations', and to consider the recommendations made by the National Committee for Uniform Succession Laws. ${ }^{125}$ In relation to family provision, the Inquiry sought submissions regarding: the factors affecting the settlement of claims; the time limits within which a claim must be made; the problems of opportunistic claims and the excessive costs that are incurred in responding to them; the possible introduction of notional estate provisions in Victoria; what the purpose of family provision claims should be; eligibility to claim; whether

\footnotetext{
${ }^{121}$ Ibid [81].

122 Ibid [90].

${ }^{123}$ VLRC, Wills, Consultation Paper No 11 (2013); VLRC 2013 Family Provision Paper, above n 90; VLRC, Intestacy, Consultation Paper No 13 (2013); VLRC, Executors, Consultation Paper No 14 (2013); VLRC, Debts, Consultation Paper No 15 (2013); VLRC, Small Estates, Consultation Paper No 16 (2013).

${ }^{124}$ VLRC, Costs Rules in Succession Proceedings, Short Information Paper (2013).

125 Queensland Law Reform Commission, National Committee for Uniform Succession Laws, Consolidated Report to the Standing Committee of Attorneys General on the Law of Wills, Miscellaneous Paper No 29 (1997); Queensland Law Reform Commission, National Committee for Uniform Succession Laws, Family Provision Supplementary Report to the Standing Committee of Attorneys, General Report No 58 (2004).
} 
the costs rules and principles should be amended, ${ }^{126}$ and whether costs in family provision claims are impacting unfairly on estates. ${ }^{127}$ This article will now address the problems associated with costs and the options proposed by the VLRC to restrict standing to claim.

The first option proposed by the VLRC is to implement the proposals of the National Committee for Uniform Succession Laws. ${ }^{128}$ The Uniform Succession Laws Project was completed in 2009, but any work regarding the implementation of the recommendations in the area of family provision appears to be currently on hold. ${ }^{129}$ To date, its recommendations have only been partially implemented in New South Wales in the Succession Act 2006 (NSW), and Western Australia in the Inheritance (Family and Dependants Provision) Amendment Act 2011 (WA). The Standing Committee of Attorneys-General created the Project in 1991, and a National Committee was formed in 1995. The Queensland Law Reform Commission is the coordinating agency, bringing together representatives from the law reform commissions of all other Australian jurisdictions. A number of papers have been released, including reports on family provision in 1997 and $2004 .{ }^{130}$ The aim of the Project is to create uniform succession laws across Australia, thereby easing the administration of estates of deceased persons who owned assets in different states. ${ }^{131}$

A draft Family Provision Bill 2004 was produced by the Project. Clause 6 provides that the wife, husband, de facto partner, and 'non-adult child' (meaning a minor, but not including a step-child) are 'automatically' entitled to apply. Clause 7 provides that a person to whom the deceased owed a responsibility to provide maintenance, education or advancement in life may apply to the court for a family provision order. Step-children, adult children, and other family members not 'automatically' entitled under clause 6 have to apply under this section, but there is nothing in the wording of the clause to suggest that it is intended to be limited to family members. ${ }^{132}$ The New South Wales Law Reform Commission ('NSWLRC') observed that this clause was similar to the Victorian provisions, and that the Victorian Court of Appeal had

\footnotetext{
${ }^{126}$ VLRC 2013 Family Provision Paper, above n 90, 45-7.

127 Ibid 45.

${ }^{128}$ Ibid 37-8.

${ }^{129}$ Rosalind F Croucher, 'Towards Uniform Succession Laws in Australia' (Keynote Address presented at the Trustee Corporations of Australia, National Council Dinner, Sydney, 18 April 2007).

130 See above n 125.

${ }^{131}$ Croucher, above n 129.

132 NSWLRC, Uniform Succession Laws: Family Provision, Report No 110 (2005) 10-13.
} 
interpreted 'responsibility' to mean 'moral duty'. ${ }^{133}$ Clause $10(3)(b){ }^{134}$ provides that the court may take 'undisclosed property' — that is, the 'notional estate' of the deceased, into consideration when formulating an order for provision. ${ }^{135}$ Clause 11 provides a list of matters for the court to consider in determining eligibility under clause 7 , and whether an order should be made. ${ }^{136}$ The list is quite similar to that contained in sections 91(4)(e)-(p) of the Administration and Probate Act, but states only that the court 'may' have regard to those factors, not that it 'must' as in the Victorian provisions. ${ }^{137}$ One interesting addition to the list is 'customary law' under clause $11(2)(\mathrm{m})$, meaning the customary law of Aboriginal or Torres Strait Islander communities, or any other customary law of a community to which the deceased person belonged. ${ }^{138}$ The final factor, 'any other matter', is again based on the Victorian Administration and Probate Act. ${ }^{139}$

Given the similarities between the draft Family Provision Bill 2004 and the Administration and Probate Act, it appears that, if the movement to introduce uniform succession laws advances, then the main change to the approach in Victoria would be that spouses, de facto partners, and minor children would be 'automatically' eligible to apply, while step-children, adult children, and anyone else for whom the deceased had a 'responsibility' to provide would first need to show standing under clause 7. 'Responsibility' would mean 'moral duty', as in the current test. While automatic eligibility to apply may seem an attractive feature, this does not translate to an order automatically being granted. As can be seen in the Victorian case law, a relationship based on blood ties is not enough to ensure that an order is made. The practical effect of the section is that an applicant who is a close family member, but otherwise would not be able to make out his or her claim, is allowed to skip the first jurisdictional question. This could possibly lead to applicants with weak claims choosing to proceed to trial under the false belief that 'relationship', rather than responsibility and need, is the most important factor in a family provision claim. One of the forces behind the 1997 amendment in Victoria was the recognition that the relationships and dependencies that

\footnotetext{
133 Ibid 13.

${ }^{134}$ Ibid 19.

135 Ibid 22.

${ }^{136}$ Ibid 22-3.

${ }^{137}$ The use of 'must' in the Victorian provisions has been held to mean 'so far as is relevant to the case', and therefore does not require the court to consider each factor in ss 91(4)(e)-(p) in every claim (Blair v Blair [2002] VSC 131 (23 April 2002) [2]-[3]).

${ }^{138}$ NSWLRC, above n 132, 27-8.

${ }^{139}$ Ibid 28.
} 
individuals form in contemporary society are not necessarily based on a close blood relationship. ${ }^{140}$

The 'notional estate' provisions also introduce additional uncertainty regarding the estate of the deceased person. While in Victoria an order for provision can only be made from the assets that the deceased owned at the time of death, and after the costs of the administration of the estate and the proceedings have been deducted, a 'notional estate' brings assets back into the estate that the deceased did not have legal title to at the time of death, due to inter vivos disposal. Gleeson CJ referred to this as 'an inherent weakness in the scheme of the Act, and its earlier legislative counterparts, as an instrument to deal with the mischief at which it is aimed'. ${ }^{141}$ While the New South Wales legislation does contain such a provision, ${ }^{142}$ the Victorian legislature chose not to include it in what was otherwise a very extensive amendment. The VLRC agrees that

In the absence of clear evidence demonstrating the need for such provisions to prevent people from depriving their families of provision in Victoria, or the effectiveness of such provisions in preventing people from doing this in New South Wales, arguably notional estate provisions should not be introduced in Victoria. ${ }^{143}$

It would therefore appear that the draft Family Provision Bill 2004 unnecessarily complicates the approach in Victoria, since it has two different tests for standing to claim. Furthermore, it has 51 clauses compared to nine in Part IV of the Administration and Probate Act 1958 (Vic).

The second option proposed by the VLRC is to replace the first jurisdictional question concerning whether the deceased had 'responsibility' to make provision, with the approach taken in the NSW Succession Act. ${ }^{144}$ Section 57(1) of that Act provides that an 'eligible person' may apply, which includes a person who was: the wife or husband of the deceased at the time of death; a person with whom the deceased was living in a de facto relationship at the time of death; and a child of the deceased. In addition, under the NSW Act, the court may make an order if, having regard to all the circumstances of the case (whether past or present) there are 'factors' which warrant the making of an order. ${ }^{145}$ Such an order can be made on the application of: a

\footnotetext{
${ }^{140}$ See above $\mathrm{n} 9$.

${ }^{141}$ Barns v Barns (2003) 214 CLR 169, 177.

${ }^{142}$ Succession Act 2006 (NSW) pt 3.3. See also Wade v Harding (1987) 11 NSWLR 551.

${ }^{143}$ VLRC 2013 Family Provision Paper, above n 90, 33 [2.92].

${ }^{144}$ VLRC 2013 Family Provision Paper, above n 90, 38-9.

${ }^{145}$ Succession Act 2006 (NSW) s 59(1)(b).
} 
former wife or husband; a grandchild, or a person who was a member of the household of which the deceased person was a member, ${ }^{146}$ who was at any particular time wholly or partly dependent on the deceased person; ${ }^{147}$ a former wife or husband of the deceased; ${ }^{148}$ or a person with whom the deceased was living in a close personal relationship at the time of death. ${ }^{149} \mathrm{~A}$ 'close personal relationship' is defined as a relationship, other than marriage or a de facto relationship, between two adult persons, whether related or not, who are living together and one or each of whom provides the other with domestic support and personal care. Such care would have to be provided without fee or reward, and should not be provided on behalf of another person or organisation, such as a government agency, a body corporate or a charitable or benevolent organisation. ${ }^{150}$ If Victoria were to adopt this approach, the VLRC asks whether, instead of using the term 'factors warranting', the legislation should employ a term such as 'exceptional circumstances', 'special circumstances', or 'some other test', and whether applicants should be required to satisfy this extra step. ${ }^{151}$

The third option posed by the VLRC is to keep the Victorian provisions, but limit eligibility to applicants who were dependent on the deceased and are in financial need. ${ }^{152}$ While the VLRC notes that these factors are already considered under sections 91(4)(h) and 91(4)(m), they are not a 'prerequisite to the court's exercise of jurisdiction'. ${ }^{153}$ Given that need has always been a relative concept in family provision claims, it is already in fact a prerequisite, found in jurisdictional question two. While this option may be effective in preventing opportunistic claims, without specifying that the applicant must have a certain type of family relationship with the deceased, ${ }^{154}$ how should need be defined? Presumably, it would be defined according to all the circumstances of the case, which again is already the current test. The VLRC also has concerns that such a provision would encourage 'bludging'. ${ }^{155}$ Apart from the fact that it is always within an individual's power to refuse to continue supporting someone who truly is 'bludging' off them, it is the author's experience that very few laypeople are aware of their rights under

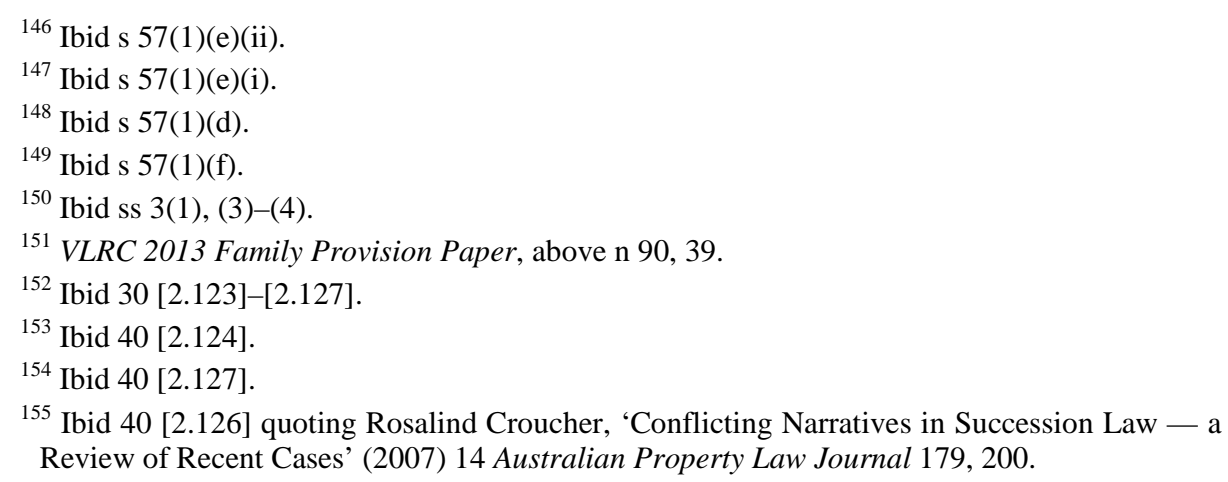


family provision law, and even if responsibility and need are established, the court may always exercise its discretion at the third stage to refuse to grant an order.

The VLRC has acknowledged that the purpose of the 1997 amendment was to address the injustice caused by the previously limited class of persons allowed to apply. It recognises that '[a]rguably, a return to a strict list approach of this nature would risk excluding legitimate claims' ${ }^{156}$ The Succession Act 2006 (NSW) and the draft legislation produced by the Uniform Succession Laws Project are significantly longer and more complex than the current Victorian provisions, which, despite their apparent flexibility, have produced remarkable consistency in the way that judges approach their task of assessing claims. In recognising the need for a jurisdictional test, rather than a statutory list, to determine standing to claim, the Victorian provisions are far more advanced than those in any other jurisdiction and the court can be trusted to exercise the wide discretion with care.

According to the VLRC, the problem leading to the current Inquiry is 'not that provision will be made for undeserving claimants, but that any opportunistic claim that is defended or settles results in legal costs that diminish the size of the estate'. ${ }^{157}$ It adds, '[t]here is a perception that people make speculative claims for family provision in the expectation that their costs will be paid by the estate, or that the personal representative will settle the matter to avoid incurring costs associated with litigation.' ${ }^{158}$ The VLRC questions first, the practice of costs being paid out of the estate; second, the effectiveness of the power to order costs against an applicant if the claim has been made frivolously, vexatiously or with no reasonable prospect of success; ${ }^{159}$ and, third, whether summary judgment is an effective way for the court to minimise the costs and impact of weak claims, given that family provision is highly fact specific, making it difficult for practitioners and the courts to confidently evaluate the merits of the case at the summary stage. ${ }^{160}$

Succession law in Victoria currently contains an exception to the general rule governing costs in civil proceedings. Section 97(6) of the Administration and Probate Act 1958 (Vic) provides the court with the discretion to make any order for the costs of an application that is, in the court's opinion, just. If the litigation was the deceased's 'fault' (for example, if the deceased failed to

\footnotetext{
${ }^{156}$ VLRC 2013 Family Provision Paper, above n 90, 36 [2.108]. See also above n 9.

${ }^{157}$ VLRC 2013 Family Provision Paper, above n 90, 25 [2.43].

${ }^{158}$ Ibid 25 [2.45] (footnote omitted).

${ }^{159}$ Administration and Probate Act 1958 (Vic) s 97(7); VLRC 2013 Family Provision Paper, above n 90, 26-7 [2.46]-[2.54].

${ }^{160}$ VLRC 2013 Family Provision Paper, above n 90, 27-8 [2.55]-[2.59].
} 
properly exercise their freedom of testation), or the proceeding was a necessary inquiry into the estate (for example, in matters of questionable testamentary capacity), then costs for all parties may be awarded out of the estate, usually on a solicitor/client basis. ${ }^{161}$ The VLRC referred to a Report produced by Vines, ${ }^{162}$ which found that, in many cases, the cost of taking a matter to trial is out of 'proportion' to the order for provision actually received. ${ }^{163}$ For example, in Collicoat $v$ McMillan ${ }^{164}$ Ormiston $\mathrm{J}$ had to defer the payment of costs out of the estate, as any order otherwise would have necessitated the sale of the family farm, which was the subject matter of the claim — 'and that would defeat the object of my making further provision'. ${ }^{165}$

Vines discovered that far more claims are made in New South Wales (in proportion to the number of applications for probate and letters of administration), and that costs are far higher. This suggests that the problem of cost would not be fixed by limiting eligibility to claim. Rather, Vines believes that there is an established 'culture' of mediation in Victoria, ${ }^{166}$ meaning that parties are less likely to require a trial to resolve their dispute, despite section 91(4)(a) seeming to making things more complicated.

In Victoria, applicants who bring unsuccessful claims that were nevertheless not frivolous or vexatious, usually receive their costs from the estate. ${ }^{167}$ In addition, the failure of a claim at the first stage of jurisdiction, due to a finding that the deceased did not owe the applicant a moral duty to provide, will not automatically lead to costs being ordered against the applicant. Coombes $v$ Ward $^{168}$ is an example. The applicant was an elderly man who had been adopted out by the deceased, and he claimed based on this blood relationship. His application was dismissed, but McDonald J held that

there were real questions of fact and law to be determined. The fact that I accepted the evidence of the defendant ... in preference to that of the plaintiff ... does not mean and it does not follow that the application of the

\footnotetext{
${ }^{161}$ Di Cecco v Contini (No 2) [2004] VSC 243 (25 June 2004) [3].

${ }^{162}$ VLRC 2013 Family Provision Paper, above n 90, 28-9 [2.61]-[2.64] citing Prue Vines, 'Bleak House Revisited? Disproportionality in Family Provision Estate Litigation in New South Wales and Victoria', Research Report (Australian Institute of Judicial Administration) 2011.

${ }^{163}$ Vines, above n 162, 31.

164 [1999] 3 VR 803.

165 Ibid 831-2.

166 Vines, above n 162, 32; ABC Radio National, 'Fights Over Wills', The Law Report, 13 December 2011 (Damien Carrick and Prue Vines) <http://www.abc.net.au/radionational/ programs/lawreport/fights-over-wills/3728174>.

${ }^{167}$ Singer v Berghouse (1993) 67 ALJR 708, 709.

168 [2002] VSC 61 (21 March 2002).
} 
plaintiff was made frivolously, vexatiously or with no reasonable prospect of success. ${ }^{169}$

The applicant appealed the dismissal of his claim, but died while he was waiting for it to be heard. His widow continued the claim as his personal representative, and the claim was again dismissed. The widow did not have costs awarded against her personally, Bongiorno AJA directing that it was more appropriate for costs to be paid from the estate of the deceased applicant. $^{170}$

If the court is satisfied that an application has been made frivolously, vexatiously, or despite having no reasonable prospect of success, the court may order that the costs of the proceeding be borne by the applicant. In Victoria, section 97(7) of the Administration and Probate Act can also be used against defendant executors who act unreasonably, ${ }^{171}$ for example through refusing to accept a reasonable offer of settlement. This power was introduced in the 1997 amendment to protect estates from a 'flood' of opportunistic claims, now that 'anyone' could claim. The VLRC is concerned that section 97(7) is not effective. ${ }^{172}$ Hewinson $v$ Saul (No 2) ${ }^{173}$ is one of the few cases to explore the application of this section. The applicant was a 44-yearold businessman claiming from the estate of his 25-year-old ex-girlfriend, who died in a car accident. Her only asset was a small life insurance policy, which she left to her family. Wodak J held that the claim was 'hopeless', ${ }^{174}$ and ordered costs against the applicant on an indemnity basis. ${ }^{175}$ Had Wodak J not made this order, it can be imagined that the entire estate of the deceased would have been consumed by costs.

The alternative scenario is where the estate is depleted by costs, due to the executor having to defend a weak or speculative claim. It is important to first understand that not all unsuccessful claims are inappropriate. For example, it may be clear that the deceased did have a responsibility to provide for the applicant, and did not make adequate provision, but it may be that there was a separate plaintiff or defendant beneficiary who had a more urgent claim, and the estate was not sufficient to fund both. While this type of problem would ideally be recognised early, and resolved at mediation, there may be enough

\footnotetext{
${ }^{169}$ Coombes v Ward (No 2) [2002] VSC 84 (27 March 2002) [17].

${ }^{170}$ Coombes v Ward [2004] VSCA 51 (4 March 2004) [33].

${ }^{171}$ Oliveri v Oliveri (Unreported, County Court of Victoria, Ostrowski J, 27 November 2003) [59].

${ }^{172}$ VLRC 2013 Family Provision Paper, above n 90, 29 [2.66].

${ }^{173}$ [2007] VCC 1115 (12 September 2007).

${ }^{174}$ Ibid [39].

${ }^{175}$ Ibid [54].
} 
uncertainty to make it worth going to trial. This is why summary judgment is relatively rare in family provision matters.

An analogy may be drawn with applications for extensions of time to make a claim, ${ }^{176}$ which are readily granted if the case is merely 'arguable', ${ }^{177}$ even where there has been a long delay. ${ }^{178}$ The VLRC is concerned about the effectiveness of summary judgment to deal with weak claims at an early stage. ${ }^{179}$ Webb $v$ Ryan $^{180}$ is an example of a speculative claim that successfully avoided summary judgment, and went on to fail, with costs ordered against the applicant. In refusing the application for summary judgment, Zammit AsJ accepted the plaintiff's submissions that: it is 'best' to leave Part IV cases to trial; the claim was unusual; the defendant's application for summary judgment had been made too late; and if the plaintiffs completely failed, then the court could use its power under the Act to 'recompense' the estate. ${ }^{181}$ While the case did raise a factual scenario that had not yet been tested under the provisions - concerning a relationship between long-term business partners and friends - it took five sitting days, 37 affidavits and 16 cross-examinations ${ }^{182}$ to determine that the six plaintiffs had failed to establish that the deceased owed them a responsibility.

Webb $v$ Ryan appears to have been argued on the basis that the applicant's relationship with the deceased 'was for all practical purposes a family relationship'. ${ }^{183}$ While at one point the financial affairs of the parties had been closely intertwined, as one would expect in a family business, the claim appears to have been motivated by an agreement of the deceased to bequeath to the applicants the proceeds of life insurance policies, in exchange for investment in the business. ${ }^{184}$ Before he died, the deceased paid out the applicants, and changed his will to reflect this. ${ }^{185}$ As the plaintiffs would not have been able to make out a claim under contract law, or establish that a trust

\footnotetext{
${ }^{176}$ Administration and Probate Act 1958 (Vic) s 99.

${ }^{177}$ Re Walker [1967] VR 890, 892.

${ }^{178}$ See, eg, Ashhurst v Moss (2006) 14 VR 291; Ansett v Moss [2008] VSC 277 (25 July 2008), brought more than 24 years out of time. This area is further explained in M Groves, 'All the Time in the World: Extensions of Time for Family Provision Claims' (2013) 87(3) Law Institute Journal 42.

${ }^{179}$ VLRC 2013 Family Provision Paper, above n 90, 27-8.

180 [2012] VSC 377 (3 September 2012).

${ }^{181}$ Webb v Ryan [2011] VSC 461 (19 September 2011) [30]-[33] citing Moerth v Moerth (No 2) [2011] VSC 275 (22 June 2011).

${ }^{182}$ Webb v Ryan [2012] VSC 377 (3 September 2012) [4].

${ }^{183}$ Ibid [13].

${ }^{184}$ Ibid [13], [39].

${ }^{185}$ Ibid [2].
} 
had arisen in these circumstances, it seems that they turned to family provision, hoping that the flexible provisions and wide discretion would work in their favour. In ordering a mix of party/party and solicitor/client costs, Whelan J commented that 'the plaintiffs and their advisers were, or ought to have been, aware that their claim was unusual and was, on any view, at the very margins of what Part IV of the Act provides for'. ${ }^{186}$

While the court may be hesitant in granting summary judgment, not many applications for summary judgment appear to be made. While parties may be unwilling to risk incurring additional costs if an application for summary judgment is refused, there are no data available regarding rates of settled or abandoned claims, where summary judgment would theoretically have been applied for and granted. The overall effectiveness of summary judgment is therefore unclear.

Civil litigation in general is expensive. While it obviously makes sense for the successful applicant's costs, and the executor's costs of defending a claim, to be paid out of the estate, the question becomes more complicated when the claim is not frivolous or vexatious, but has a questionable prospect of success. It is understandable that the court does not wish to further burden an unsuccessful plaintiff, who is already in financial need, with the requirement to pay his or her own costs. However, the usual practice in civil litigation is that a plaintiff has to weigh this risk against the prospects of success. A deceased estate should not be treated as a pool of assets that may be readily utilised by anyone who may or may not be found to have an interest in it. The practice of all costs being paid out of the estate needs to be re-examined.

\section{Conclusion}

Family provision legislation was introduced in New Zealand in 1900, and Victoria was the first jurisdiction in Australia to adopt legislation of this kind. The aim of family provision legislation is to ensure that an individual uses the freedom of testation to make adequate and proper provision for those to whom the individual owes a moral responsibility. Under the first version of the provisions in Victoria, only widows and children could claim. The legislation underwent relatively little reform until a major amendment in 1997, following an Inquiry by the VLRC, which found that the narrow terms of the Administration and Probate Act 1958 (Vic) were leading to many cases of injustice. The 1997 reforms removed the statutory list of eligible applicants and replaced it with the jurisdictional question, 'Did the deceased have a responsibility to make provision for the applicant?'

${ }^{186}$ Webb v Ryan (Costs) [2012] VSC 431 (20 September 2012) [52]. 
While the 1997 amendment was revolutionary in recognising the necessity of a discretion-based approach, the unrestricted category of applicants left the estate vulnerable to speculative claims. The court has appeared hesitant to utilise its power to order costs against applicants with claims that are frivolous, vexatious or have no reasonable prospect of success.

These factors have led the VLRC to conduct the current Inquiry into Succession Law. Among other things, it focuses on who should be eligible to make an application for family provision, and whether the costs of all parties should be paid from the estate of the deceased, regardless of the success of the claim. The VLRC has made a number of suggestions for reform, including the implementation of the draft Family Provision Bill 2004 that was developed by the National Committee for Uniform Succession Laws; or the adoption of the terms of the NSW Succession Act.

The Inquiry needs to be viewed in light of the previous inquiry, and the concerns that led to the 1997 reform. The primary concern was that a restricted test for standing to claim was causing injustice in a modern society, where individuals form many different types of relationship involving responsibility and dependency, which may not be based on blood or legal ties. The Victorian provisions are advanced in recognising this, and their simplicity is preferable to the options for reform proposed by the current Inquiry.

Family provision is fact specific, and it can be difficult to predict the outcome of a claim. Not all unsuccessful applications can be properly described as frivolous or vexatious. However, the usual course of events in litigation is that plaintiffs must take the risk of failing, and bear their own costs. The court should be more willing to adopt general costs practices in family provision claims, to protect the estate for those whom the deceased had responsibility to provide. 